\title{
Analisis Kemampuan Literasi Matematis Siswa SMA Kelas X Dalam Menyelesaikan Soal Tipe Pisa Konten Change and Relationship
}

\author{
Rohmah Nila Farida ${ }^{1}$, Abd. Qohar ${ }^{2}$, Swasono Rahardjo ${ }^{3}$ \\ ${ }^{1,2,3}$ Program Studi Pascasarjana Pendidikan Matematika, Fakultas Matematika dan Ilmu Pengetahuan Alam, Universitas \\ Negeri Malang. Jalan Semarang 5 Malang, Indonesia \\ rohmahnilaf@yahoo.co.id
}

\begin{abstract}
This study aims to describe the achievement of students' mathematical literacy skills in solving PISA type problems with content change and relationship. The type of research used is descriptive research with a qualitative approach. Data was collected by means of tests of mathematical literacy skills and interviews. The research subjects were students of class X SMAN Mojoagung in the academic year 2021/2022, each of which had high, medium, and low abilities. The data obtained were then reduced and analyzed qualitatively by taking into account the indicators of students' mathematical processing ability. The results of this study indicate that high-ability students are able to demonstrate good mathematical literacy skills, namely students are able to fulfill all three aspects of the mathematical process, namely formulate, employ and interpret well. Students with moderate abilities are only able to meet two indicators in the mathematical process aspect, namely formulate and employ. Low-ability students cannot fulfill all indicators in the mathematical process aspect, low-ability students only meet one aspect of the mathematical process, namely formulate. For further researchers, in order to examine the factors that influence the low ability of mathematical literacy at the high school/equivalent level.
\end{abstract}

Keywords: Mathematical literacy ability, PISA

\begin{abstract}
Abstrak
Penelitian ini bertujuan untuk mendeskripsikan capaian kemampuan literasi matematis siswa dalam menyelesaikan soal tipe PISA konten change and relationship. Jenis penelitian yang digunakan adalah penelitian deskriptif dengan pendekatan kualitatif. Pengumpulan data dilakukan dengan tes kemampuan literasi matematis dan wawancara. Subjek penelitian adalah peserta didik kelas X SMAN Mojoagung Tahun Pelajaran 2021/2022 yang masing-masing satu orang berkemampuan tinggi, sedang dan rendah. Data yang didapatkan kemudian direduksi dan dianalisis secara kualitatif dengan memperhatikan indikator-indikator kemampuan proses matematis siswa. Hasil penelitian ini menunjukkan bahwa siswa berkemampuan tinggi mampu menunjukkan kemampuan literasi matematis yang baik, yakni siswa mampu memenuhi ketiga aspek proses matematis yakni formulate, employ dan interprete dengan baik. Siswa berkemampuan sedang hanya mampu memenuhi dua indikator pada aspek proses matematis yakni formulate dan employ. Siswa berkemampuan rendah tidak dapat memenuhi seluruh indikator pada aspek proses matematis, siswa berkemampuan rendah hanya memenuhi satu aspek proses matematis yakni formulate. Bagi peneliti selanjutnya, agar meneliti faktor-faktor yang mempengaruhi rendahnya kemampuan literasi matematis pada jenjang SMA/sederajat.
\end{abstract}

Kata kunci: Kemampuan literasi matematis, PISA

Copyright (c) 2021 Rohmah Nila Farida, Abd. Qohar, Swasono Rahardjo

$\triangle$ Corresponding author: Rohmah Nila Farida

Email Address: rohmahnilaf@yahoo.co.id (Jalan Kertorejo-Prigen, Jawa Timur)

Received 02 August 2021, Accepted 24 August 2021, Published 26 August 2021

\section{PENDAHULUAN}

Pendidikan pada abad ke-21 menuntut semua orang untuk mengembangkan seluruh kompetensi yang dimilikinya. Pembelajaran di sekolah pada abad ke-21 membutuhkan kemampuan berkomunikasi, berkolaborasi, berpikir kritis dan keterampilan memecahkan masalah (Van Laar et al, 2020). Hal ini akan tercapai apabila siswa memiliki kemampuan literasi matematis yang memadai. Kemampuan literasi matematis sangat penting untuk dimiliki oleh siswa karena, dapat membantu siswa menggunakan matematika dalam kehidupan sehari-hari (Dewantara, Zulkardi \& Darmawijoyo, 2015; Malasari, 
Herman \& Jupri, 2017; Genc \& Erbas, 2019; Jannah, Putri \& Zulkardi 2019; Nizar, Putri dan Zulkardi, 2018; Rizki \& Priatna, 2019; Hwang \& Ham, 2021). Selain itu, literasi matematis juga menuntut siswa untuk mengkomunikasikan dan menjelaskan fenomena yang dihadapinya dengan konsep matematika.

Kemampuan literasi matematis merupakan kemampuan siswa untuk memformulasikan, menggunakan, dan menafsirkan matematika dalam berbagai konteks, termasuk kemampuan melakukan penalaran secara matematis. Dengan kata lain, siswa mampu menggunakan konsep, prosedur, fakta dan alat matematika untuk mendeskripsikan, menjelaskan, dan memprediksi fenomena (OECD, 2019). Seorang siswa dikatakan memiliki literasi yang baik apabila ia mampu menganalisis, bernalar, dan mengkomunikasikan pengetahuan dan keterampilan matematikanya secara efektif, serta mampu memecahkan dan menginterpretasikan masalah matematika.

Kemampuan literasi matematis telah mendapat perhatian besar dalam menghadapi abad 21 (Haara et al, 2017, Hesse et al, 2015; Gravemeijer et al, 2017). Hasil penelitian Baiduri (2019). menyimpulkan bahwa literasi matematis penting dikuasai peserta didik untuk menyongsong industri 4.0. Kemampuan literasi matematis menandakan kapasitas individu dalam formulate, employ, dan interpret matematika. Ketiga proses utama tersebut merupakan aspek kemampuan proses matematis seseorang untuk dapat menghubungkan konteks masalah dengan konsep matematika dan menyelesaikan masalah.

OECD menetapkan pelevelan kemampuan literasi matematis dalam soal PISA yang digunakan dalam tes PISA tahun 2018. Kriteria level kemampuan literasi matematis yang dikembangkan OECD (2019) terdiri atas enam level. Salah satu aspek yang digunakan untuk menganalisis kemampuan literasi matematis peserta didik adalah kemampuan proses matematis. Indikator kemampuan literasi matematis dalam penelitian ini dikembangkan dari OECD (2013). Berikut ini adalah indikatorindikator kemampuan proses matematis yang digunakan pada penelitian ini:

Tabel 1. Indikator Kemampuan Proses Matematis

\begin{tabular}{|l|ll|}
\hline \multicolumn{1}{|c|}{ Proses Matematis } & \multicolumn{1}{c|}{ Indikator } \\
\hline Merumuskan (Formulate) & A1 $\begin{array}{l}\text { Mengidentikasi aspek-aspek matematika dalam } \\
\text { permasalahan yang terdapat pada situasi konteks } \\
\text { nyata serta mengidentikasi variabel yang penting }\end{array}$ \\
\cline { 2 - 3 } & A2 $\begin{array}{l}\text { Mengubah permasalahan menjadi bahasa matematika } \\
\text { atau model matematika yang sesuai ke dalam bentuk } \\
\text { variabel, gambar atau diagram yang sesuai }\end{array}$ \\
\hline Menggunakan (Employ) & B1 $\begin{array}{l}\text { Menerapkan rancangan model matematika untuk } \\
\text { menemukan solusi matematika }\end{array}$ \\
\hline Menafsirkan (Interprete) & C1 $\begin{array}{l}\text { Menafsirkan hasil matematika yang diperoleh dan } \\
\text { mengevaluasi kewajaran solusi matematika dalam } \\
\text { konteks masalah dunia nyata. }\end{array}$ \\
\hline
\end{tabular}

Penilaian internasional merupakan indikator penting dalam mengevaluasi sistem pendidikan suatu negara (Yalcin et al, 2012). Salah satu bentuk penilaian internasional yang didalamnya memuat tentang perkembangan matematika suatu negara yaitu PISA atau for International Student Assessment. PISA berfungsi sebagai tolak ukur antar negara dan mengidentifikasi faktor-faktor yang dapat 
mempengaruhi hasil yang berbeda dari berbagai negara (Seidel \& Prenzel, 2008). Sedangkan menurut Gomes et al (2020), PISA merupakan penilaian yang diakui oleh dunia, sehingga hasilnya benar-benar dapat menjadi tolak ukur posisi literasi matematis siswa Indonesia. PISA dilaksanakan tiga tahun sekali sejak tahun 2000 untuk mengetahui literasi matematis, sains dan membaca siswa yang berusia 15 tahun (Yilmazer \& Masal, 2014). Tujuan dari penilaian ini adalah untuk mengukur prestasi literasi membaca, matematika, dan sains siswa sekolah di negara-negara peserta. Berdasarkan penelitian yang dilakukan oleh PISA pada tahun 2002 - 2018 menunjukkan bahwa peringkat siswa Indonesia selalu berada di peringkat 12 negara terendah dari negara-negara yang berpartisipasi pada PISA (Stacey, 2011). Terlihat bahwa Indonesia pada tahun 2015 berada pada peringkat 63 dari 75 negara, dan pada tahun 2018 dari 79 negara Indonesia menempati peringkat ke-73. Kemampuan siswa indonesia dalam menjawab soalsoal PISA masih termasuk kategori yang rendah dari tahun-tahun sebelumnya sejak mengikuti program tersebut. Survei tersebut menempatkan Indonesia pada posisi 10 negara terendah peringkat literasi matematikanya (Nugrahanto \& Zuchdi, 2019).

PISA mengembangkan beberapa soal berdasarkan 4 konten yaitu konten perubahan dan hubungan (change and relationship), konten bentuk dan ruang (shape and space), konten kuantitas (quantity) dan konten ketidakpastian dan data (uncertainty and data) (Ehmke et al, 2020; Nusantara et al, 2021; Edo et al, 2013). Konten change and relationship merupakan salah satu konten dari PISA yang sangat penting untuk dikuasai siswa karena berkaitan dengan kehidupan sehari-hari dalam mendeskripsikan, memodelkan dan menginterpretasikan pertumbuhan dan fenomena (OECD, 2018; Ahyan et al, 2014; Nusantara et al, 2020b). Namun pentingnya konten change and relationship ini tidak sejalan dengan fakta bahwa siswa di Indonesia kurang mampu dalam menyelesaikan soal matematika tipe PISA fenomena (Wijaya et al, 2014). Secara khusus, hasil mengejutkan yang dirilis oleh PISA 2018 menunjukkan bahwa kemampuan siswa di Indonesia pada konten change and relationship jauh dibawah rata-rata dengan skor 379 dari 489 (OECD 2019). Beberapa hasil penelitian menunjukkan faktor-faktor yang mendasari rendahnya skor siswa di Indonesia menyelesaikan soal-soal PISA, seperti : siswa tidak terbiasa dalam menyelesaikan masalah yang berkaitan dengan kehidupan sehari-hari, seperti PISA (Wijaya et al, 2014; Novita et al, 2014); guru hanya memberikan latihan soal-soal rutin pada level yang rendah (Novita et al, 2012; Putri \& Zulkardi, 2018; Permatasari et al, 2018); dan keterbatasan sumber belajar yang disediakan oleh buku teks matematika siswa (Wijaya et al, 2015). Berdasarkan kenyataan tersebut, siswa di Indonesia perlu dibiasakan untuk menyelesaikan masalah matematika seperti soal tipe PISA agar dapat meningkatkan kemampuan literasi matematis siswa di tingkat internasional (Nusantara et al, 2020a).

Keberhasilan siswa di Indonesia dalam menyelesaikan soal-soal PISA ditentukan oleh sistem evaluasi guru dalam mengembangkan literasi matematis siswa (Johar, 2012). Dengan mengerjakan soal-soal yang berkarakteristik model PISA dapat meningkatkan kemampuan penalaran, berpikir dan kreativitas siswa (Novita et al, 2012). Dalam proses pembelajaran dibutuhkan pendekatan pembelajaran berdasarkan masalah untuk meningkatkan penalaran siswa. Maka dari itu, untuk mengatasi rendahnya 
kemampuan literasi matematis siswa, guru dapat melatih siswa dengan memberikan soal bertipe PISA secara rutin. Diharapkan setelah siswa terbiasa dengan soal non rutin siswa akan terbiasa dalam menyelesaikan soal tipe PISA dan kemampuan literasi matematis siswa akan membaik dan meningkat. Oleh karena itu, perlu untuk dilakukan penelitian terkait kemampuan literasi matematis siswa tersebut, terutama pada tingkat SMP ditinjau dari konten change and relationship.

Kerangka konseptual penelitian pada dasarnya adalah kerangka berpikir mengenai alur dari penelitian, alur penelitian tersebut akan dibuat suatu hubungan antara konsep-konsep yang akan diamati melalui penelitian yang akan dilaksanakan. Adapun kerangka konsep pada penelitian ini akan dijelaskan pada gambar di bawah ini dan lebih jelasnya akan dijelaskan pada pembahasan selanjutnya:

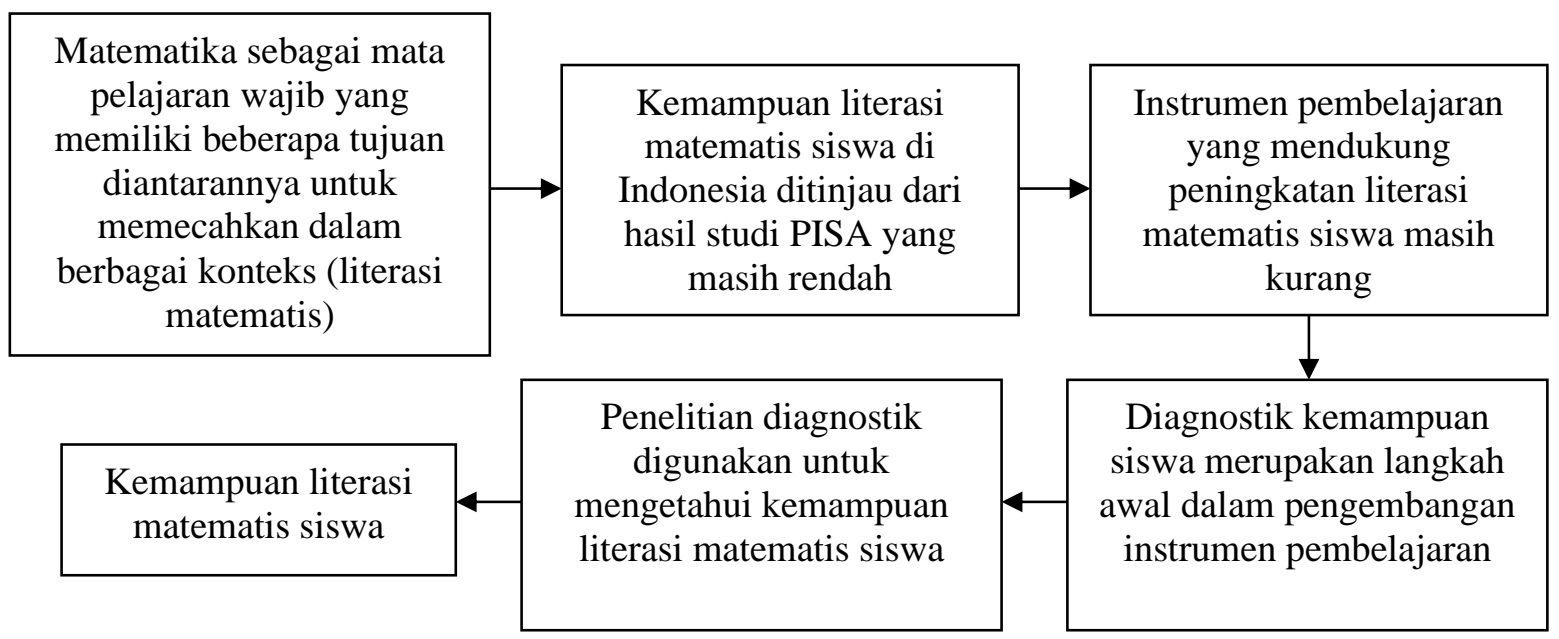

Gambar 1. Diagram Kerangka Konseptual Penelitian

Matematika adalah salah satu mata pelajaran wajib di tingkat pendidikan dasar sampai tingkat menengah. Salah satu tujuan adanya pembelajaran matematika yaitu agar siswa memiliki kemampuan dalam memahami masalah, merancang model matematika, menyelesaikan model dan menafsirkan solusi matematika yang diperoleh. Masalah tersebut bukan hanya masalah pada lingkup ilmu matematika saja, akan tetapi juga masalah dalam berbagai konteks kehidupan. Kemampuan matematis dalam memecahkan masalah dengan berbagai konteks dikenal dengan literasi matematis. Penilaian Internasional yang mengangkat kemampuan literasi matematis siswa yaitu PISA. Capaian siswa di Indonesia pada studi PISA masih belum memuaskan karena masih berada di bawah rata-rata internasional.

Salah satu latar belakang perubahan kurikulum dan kebijakan merevisi kurikulum di setiap periodenya adalah untuk meningkatkan kemampuan literasi matematis siswa. Langkah tersebut diwujudkan dengan penyusunan perangkat pembelajaran yang dapat memberikan pengalaman kepada siswa dalam menyelesaikan masalah dalam berbagai konteks. Namun kenyataannya, perangkat pembelajaran di sekolah masih kurang mendukung dalam pengembangan kemampuan literasi matematis siswa. Hal tersebut dapat dilihat dari instrumen penilaian hasil belajar siswa yang masih kurang mengaitkan dengan berbagai konteks kehidupan sehari-hari. Hal ini tidak sejalan dengan karakteristik 
penilaian pada tes PISA. Ketersediaan perangkat yang mendukung dalam meningkatkan kemampuan literasi matematis siswa, perlu didasari dengan informasi mengenai potensi yang dimiliki oleh siswa sehingga perangkat pembelajaran akan tersusun tepat sasaran.

Pada penilaian PISA terdapat tiga aspek, yaitu proses matematis, konten matematis, dan konteks matematis. Salah satu aspek pada konten PISA yaitu konten change and relationships. Konten change and relationship merupakan konten dalam PISA yang sering dinyatakan dengan persamaan atau hubungan yang bersifat umum, seperti penambahan, pengurangan, dan pembagian. Konten Change and Relationship sangat erat kaitannya dengan materi dalam kurikulum yaitu aljabar. Materi aljabar merupakan salah satu materi matematika dalam kurikulum sekolah yang banyak dijumpai dalam konteks kehidupan sehari-hari. Namun, siswa masih sering mengalami kesulitan ketika dihadapkan dengan permasalahan kehidupan sehari-hari. Oleh karena itu peneliti tertarik untuk meneliti mengenai kemampuan literasi matematis siswa dalam menyelesaikan soal tipe PISA pada konten Change and Relationship.

Penilaian diawali dengan memberikan tes kemampuan literasi matematis dan wawancara sehingga diperoleh data yang relevan. Selanjutnya peneliti memilih subjek penelitian untuk dilakukan wawancara. Peneliti memilih subjek masing-masing satu siswa dengan kategori berkemampuan tinggi, sedang dan rendah. Selanjutnya peneliti menganalisis jawaban tertulis siswa dan wawancara kepada tiga subjek berdasarkan kategori kemampuan tinggi, sedang dan rendah. Melalui data yang telah dianalisis tersebut, diperoleh informasi kemampuan proses matematis setiap siswa berkemampuan tinggi, sedang dan rendah.

Berdasarkan penelitian yang sudah ada mengenai kemampuan literasi matematis, pada umumnya menjelaskan sampai level berapa kemampuan literasi matematis siswa tersebut. Salah satunya yaitu hasil penelitian (Julie et al, 2017) yang meneliti level kemampuan literasi matematis siswa pada konten quantity dan change and relationship. Persamaan penelitian diatas dengan penelitian penulis yaitu, konten change and relationship. Perbedaan penelitian diatas dengan penelitian penulis yaitu penelitian (Julie et al, 2017) meneliti level berapa kemampuan literasi matematis siswa pada konten quantity dan change and relationship. Sedangkan pada penelitian ini meneliti mengenai proses penyelesaian soal literasi matematis siswa berdasarkan dari kemampuan proses matematis dalam merumuskan, menggunakan dan menafsirkan matematika dalam menyelesaikan soal tipe PISA konten change and relationship. Tujuan penelitian ini yaitu untuk mendeskripsikan kemampuan literasi matematis siswa SMA kelas X dalam menyelesaikan soal tipe PISA konten change and relationship.

\section{METODE}

Jenis penelitian yang digunakan dalam penelitian ini adalah penelitian deskriptif dengan menggunakan pendekatan kualitatif. Penelitian deskriptif merupakan penelitian yang menghasilkan data deskriptif berupa kata-kata tertulis atau lisan dari orang-orang atau perilaku yang diamati (Moleong, 2016). Penelitian kualitatif adalah penelitian yang memahami fenomena apa yang dialami 
oleh subjek penelitian misalnya perilaku, persepsi, motivasi, tindakan dan lain-lain secara menyeluruh dengan cara mendeskripsikan dalam bentuk kata-kata dan bahasa pada suatu konteks khusus yang alamiah (Moleong, 2016).

Penelitian ini dilaksanakan pada peserta didik kelas X SMAN Mojoagung semester gasal tahun pelajaran 2021/2022 yang melibatkan 22 peserta didik. Penentuan subjek ditentukan dengan teknik purposive sampling. Dengan menggunakan teknik purposive sampling, diambil 3 orang siswa sebagai subjek penelitian berdasarkan tinggi, sedang dan rendahnya proses literasi siswa, tinggi diambil dari siswa bisa melakukan ketiga proses literasi, sedang melakukan dua proses literasi dan rendah hanya melakukan satu proses literasi. Instrumen yang digunakan pada penelitian ini yaitu instrumen tes kemampuan literasi matematis dan pedoman wawancara. Soal tes kemampuan tes literasi matematis terdiri dari satu soal, tes yang diberikan yaitu tipe PISA konten change and relationship. Selanjutnya, wawancara digunakan untuk mengetahui ketercapaian indikator kemampuan proses matematis yang tidak tampak pada hasil tes.

Berdasarkan hasil pekerjaan siswa, maka selanjutnya siswa diwawancara dengan menggunakan pedoman wawancara yang digunakan sebagai acuan atau arahan dalam wawancara antara peneliti dengan subjek. Kredibilitas data dengan menggunakan triangulasi sumber. Data valid kemudian dianalisis dengan tahapan reduksi data, penyajian data dan penarikan kesimpulan.

\section{HASIL DAN DISKUSI}

\section{Hasil}

Tes kemampuan literasi matematis pada penelitian ini dilakukan oleh peserta didik kelas $\mathrm{X}$ SMAN Mojoagung sebanyak 22 siswa. Penentuan subjek ditentukan dengan teknik purposive sampling. Subjek terpilih masing-masing satu orang dengan kategori berkemampuan tinggi, sedang dan rendah. Hasil pekerjaan soal tes literasi matematis kemudian dianalisis, berdasarkan indikator kemampuan proses matematis. Selanjutnya, dari hasil tes dipilih subjek penelitian untuk dilakukan wawancara. Subjek terpilih masing-masing satu siswa dengan kategori berkemampuan tinggi, sedang dan rendah. Siswa berkemampuan tinggi, sedang dan rendah selanjutnya masing-masing disebut sebagai S1, S2 dan S3. Berikut ini adalah hasil pekerjaan S1, S2 dan S3.

\section{Hasil Analisis Jawaban Subjek S1}

Pada gambar 1 berikut menunjukkan bahwa subjek S1 menuliskan beberapa informasi dalam menyelesaikan masalah, seperti harga sewa kendaraan mobil sedan dan mobil van. Subjek S1 juga menuliskan apa yang ditanyakan pada soal dan S1 membuat permisalan bahwa mobil sedan sebagai $x$ dan mobil van sebagai $y$. Setelah S1 membuat permisalan, subjek S1 mengubah masalah menjadi model matematika menjadi suatu persamaan. Setalah itu, subjek S1 menggunakan rancangan model dari persamaan yang telah subjek buat serta mengeliminasi variabel $x$ dan mensubstitusikan variabel $y$. Subjek S1 juga menuliskan kesimpulan, bahwa banyak mobil sedan dan mobil van yang disewakan pada hari itu adalah mobil sedan 23 dan mobil van sebanyak 13 yang disewakan. 


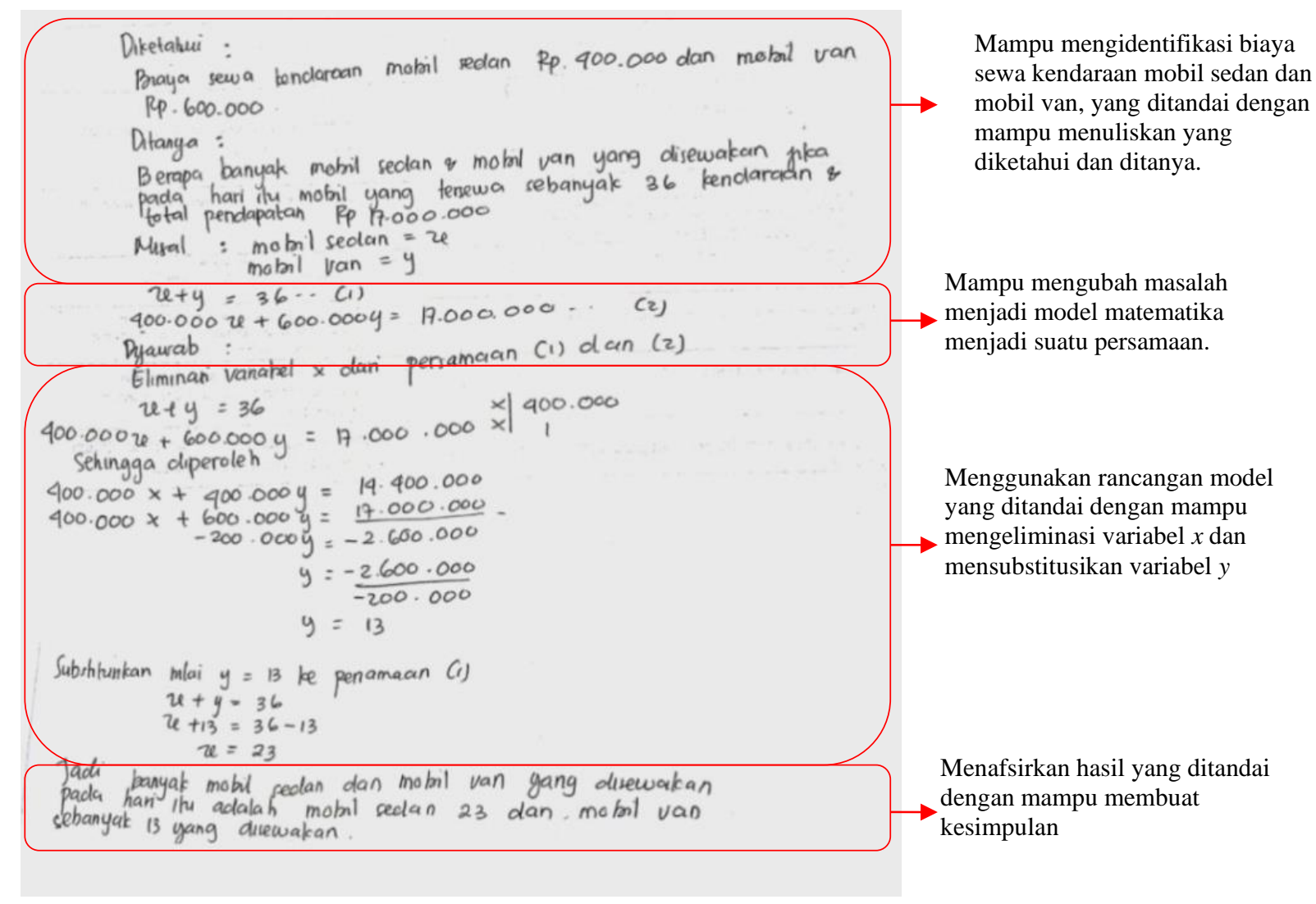

Gambar 2. Hasil Pekerjaan Subjek S1

Berdasarkan hasil jawaban tertulis siswa, peneliti kemudian mengkonfirmasi dengan hasil wawancara siswa. Berdasarkan hasil wawancara dengan subjek S1 diperoleh data bahwa subjek S1 memahami soal yang telah diberikan, sehingga dapat mengerjakan soal sesuai dengan langkah-langkah penyelesaian sampai dengan penarikan kesimpulan.

\section{Hasil Analisis Jawaban Subjek S2}

Pada gambar 3 berikut menunjukkan bahwa subjek S2 menuliskan beberapa informasi dalam menyelesaikan masalah, seperti harga sewa kendaraan mobil sedan dan mobil van. Subjek S2 juga menuliskan apa yang ditanyakan pada soal yaitu berapa banyak mobil sedan dan mobil van yang disewakan pada hari itu serta membuat permisalan bahwa mobil sedan sebagai $x$ dan mobil van sebagai y. Setelah S2 membuat permisalan, subjek S2 mengubah masalah menjadi model matematika menjadi suatu persamaan. Setelah itu, subjek S2 menggunakan rancangan model dari persamaan yang telah subjek buat serta mengeliminasi variabel $x$ dan mensubstitusikan variabel $y$. Pada penyelesaian soal tersebut subjek S2 tidak memberikan kesimpulan berdasarkan jawaban yang telah diperoleh.

Berdasarkan hasil jawaban tertulis siswa, peneliti kemudian mengkonfirmasi dengan hasil wawancara siswa. Berdasarkan hasil wawancara dengan subjek S2 diperoleh data bahwa subjek S2 memahami konsep sistem persamaan linear dua variabel, sehingga subjek S2 dapat mengerjakan soal sesuai dengan langkah-langkah penyelesaian. Akan tetapi subjek S2 tidak mampu memberikan 
kesimpulan, hal tersebut dikarenakan subjek S2 terburu-buru pada saat menyelesaikan soal. Seharusnya siswa tersebut memberikan kesimpulan bahwa banyak mobil sedan 23 dan banyak mobil van 13 yang telah dia hitung yang disewakan pada hari itu.

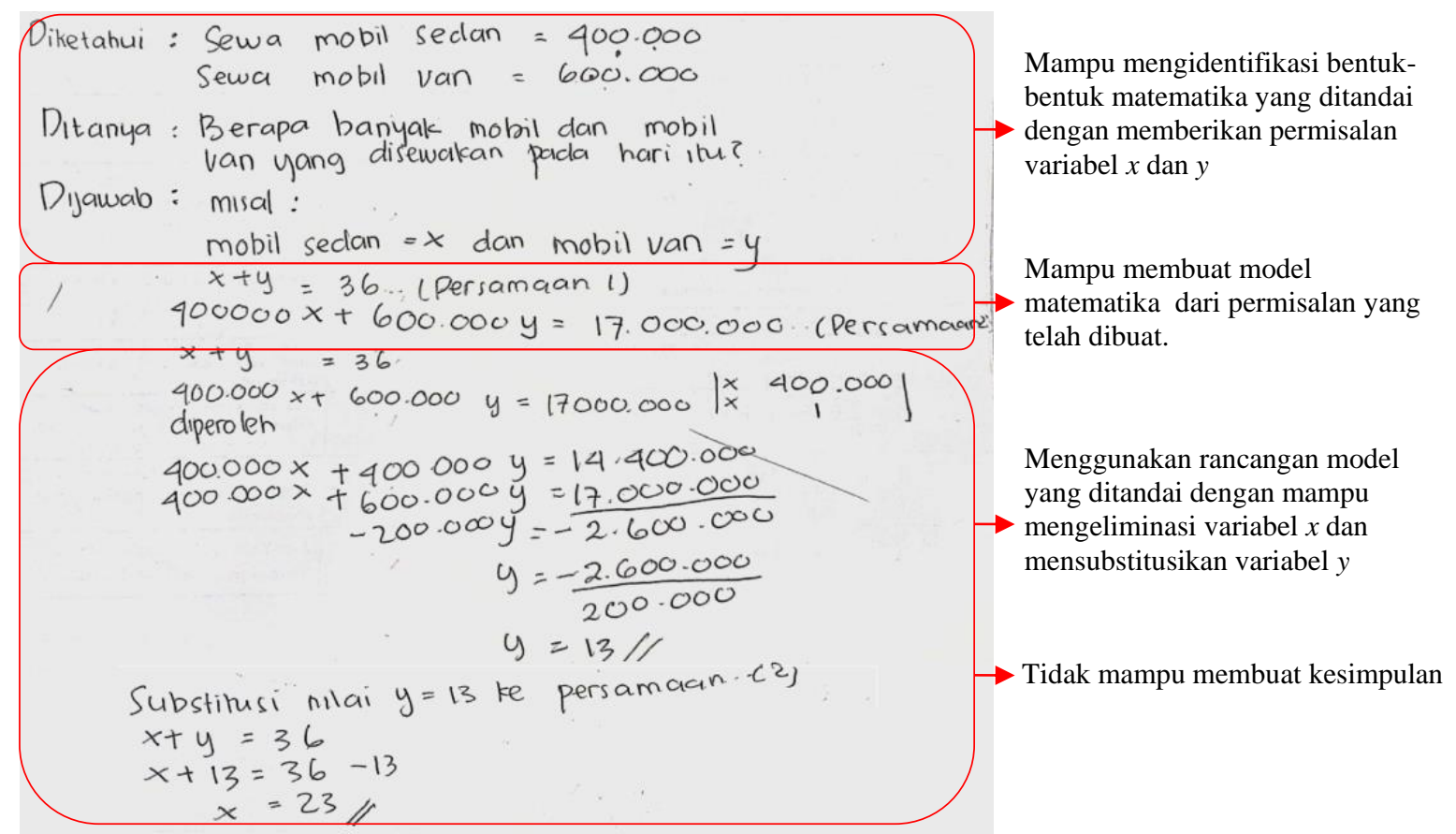

Gambar 3. Hasil Pekerjaan Subjek S2

\section{Hasil Analisis Jawaban Subjek S3}

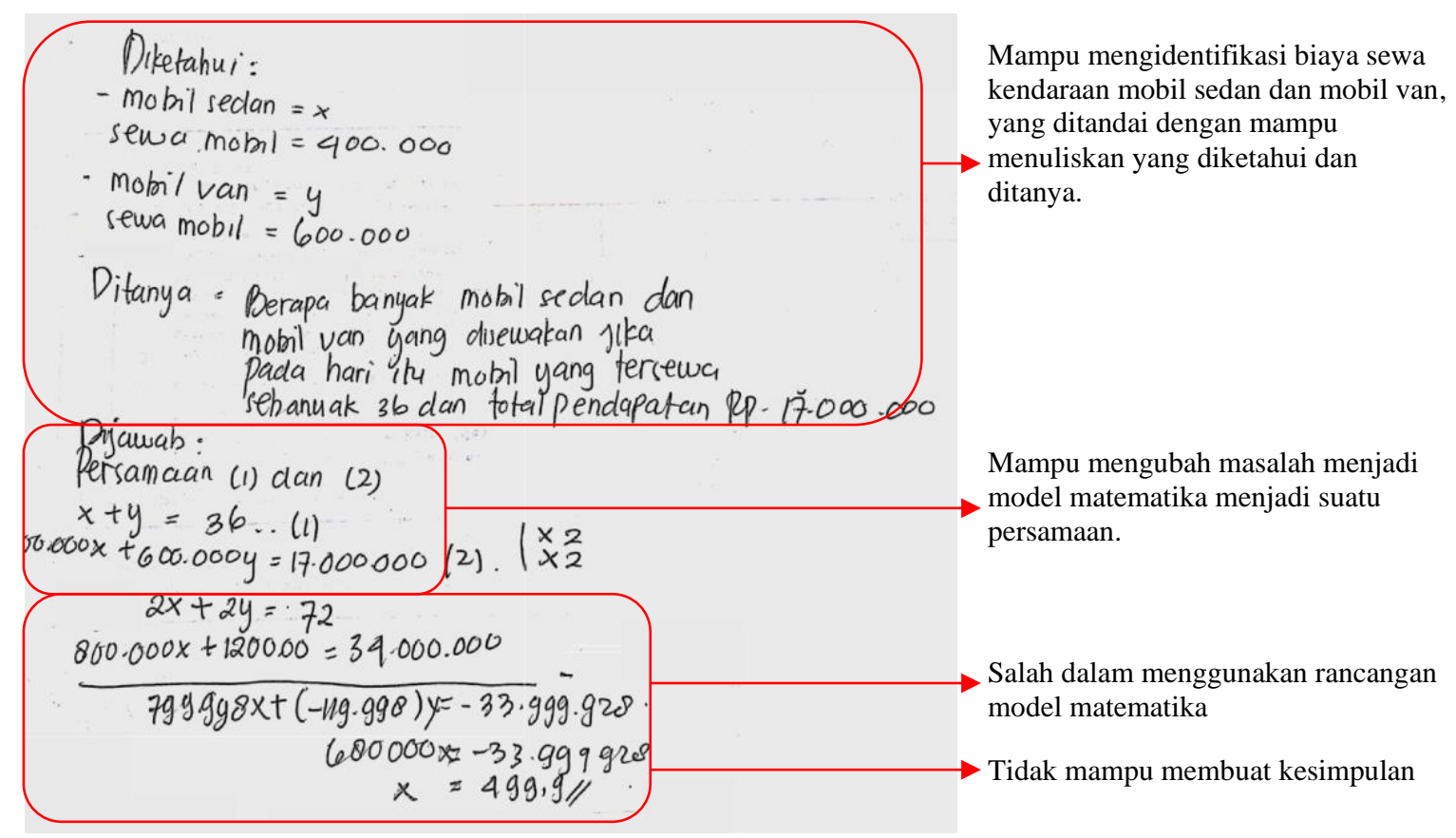

Gambar 4. Hasil Pekerjaan Subjek S3

Pada gambar 4 menunjukkan bahwa subjek S3 menuliskan permisalan bahwa mobil sedan sebagai $x$ dan mobil van sebagai $y$. Subjek S3 juga menuliskan apa yang ditanyakan pada soal yaitu 
berapa banyak mobil sedan dan mobil van yang disewakan pada hari itu jika pada hari itu mobil yang tersewa sebanyak 36 dan total pendapatan Rp. 17.000.000. Setelah itu S3 mengubah masalah menjadi model matematika menjadi suatu persamaan. Pada penyelesaian soal tersebut, subjek S3 menggunakan rancangan model dari persamaan yang telah subjek buat. Dalam menggunakan rancangan model matematika subjek S3 masih salah dalam melakukan operasi perhitungannya. Subjek S3 mengalikan masing-masing persamaan dengan 2, hal tersebut kurang tepat. Seharusnya subjek S3 mengeliminasi variabel $x$ dengan mengalikan persamaan 1 dengan 400.000. Setelah itu, dilanjutkan dengan mensubstitusikan variabel $x$ pada persamaan 2 sehingga diperoleh variabel $y$. Pada jawaban akhir, subjek S3 tidak mampu memberikan kesimpulan berdasarkan jawaban yang telah diberikan. Berdasarkan hasil jawaban tertulis siswa, peneliti kemudian mengkonfirmasi dengan hasil wawancara siswa. Berdasarkan hasil wawancara dengan subjek S3 diperoleh data bahwa subjek S3 kurang menguasai konsep pada materi spldv sehingga siswa hanya mampu sampai dengan membuat model matematikanya saja. Sehingga langkah-langkah penyelesaian yang digunakan subjek S3 masih kurang tepat serta keliru dalam melakukan perhitungan matematika.

\section{Diskusi}

\section{Pembahasan Kemampuan Literasi Matematis Siswa dalam Menyelesaikan Soal Change and Relationship Tipe Pisa}

Berdasarkan gambar 1, ditinjau dari aspek proses literasi matematis formulate, subjek S1 sudah mampu mengidentifikasi aspek-aspek matematika dalam permasalahan yang terdapat pada situasi konteks nyata serta mengidentifikasi variabel yang penting, karena siswa mampu menuliskan diketahui dan ditanyakan yang terdapat di dalam soal; mampu mengubah permasalahan menjadi bahasa matematika atau model matematika yang sesuai ke dalam bentuk variabel, gambar atau diagram yang sesuai karena mampu membuat permisalan mobil sedan dan mobil van sebagai variabel $x$ dan $y$. Hal ini menunjukkan bahwa S1 mampu memenuhi indikator A1 dan A2 dengan baik. Ditinjau dari proses literasi matematis employ, subjek S1 sudah mampu menerapkan rancangan model matematika untuk menemukan solusi matematika dengan baik, karena mampu mengubah permasalahan model matematika menjadi suatu persamaan. Hal ini didukung dari hasil penelitian yang dilakukan oleh Zulkardi \& Junaidi (2013) yang menyatakan bahwa pada saat siswa diberikan soal bertipe PISA, siswa sudah dapat mengembangkan dengan baik, siswa sudah dapat memperoleh informasi dari soal yang diberikan, sebagian siswa juga sudah dapat menuliskan model matematisnya akan tetapi ada juga siswa yang masih kesulitan dalam menuliskan model matematisnya. Sedangkan ditinjau dari proses literasi matematis interprete subjek S1 sudah mampu menafsirkan hasil matematika yang diperoleh dan mengevaluasi kewajaran solusi matematika dalam konteks masalah dunia nyata, karena subjek S1 mampu memberikan kesimpulan atas jawaban yang telah dia berikan. Dengan demikian, subjek S1 sudah mampu melakukan ketiga proses literasi matematis, sehingga kemampuan literasi yang dimiliki oleh S1 sudah tergolong tinggi, karena mampu memenuhi ketiga proses literasi matematis. Hal ini sejalan dengan penelitian Sari 
(2015) yang menyatakan bahwa, seseorang yang memiliki kemampuan literasi matematis yang baik dapat mencapai ketiga proses matematis dalam menyelesaikan permasalahan matematika.

Ditinjau dari proses literasi matematis formulate, subjek S2 sudah mampu mengidentifikasi aspek-aspek matematika dalam permasalahan yang terdapat pada situasi konteks nyata serta mengidentifikasi variabel yang penting, karena mampu menganalisis menuliskan diketahui dan ditanyakan yang terdapat di dalam soal; mampu mengubah permasalahan menjadi bahasa matematika atau model matematika yang sesuai ke dalam bentuk variabel, gambar atau diagram yang sesuai karena mampu membuat permisalan mobil sedan dan mobil van sebagai variabel $x$ dan $y$. Hal ini menunjukkan bahwa bahwa S2 mampu memenuhi indikator A1 dan A2 dengan baik. Ditinjau dari proses matematis employ, subjek S2 sudah mampu menerapkan rancangan model matematika untuk menemukan solusi matematika dengan baik, karena mampu mengubah permasalahan model matematika menjadi suatu persamaan. Sedangkan ditinjau dari proses literasi matematis interprete subjek S2 tidak mampu menafsirkan hasil matematika yang diperoleh dan mengevaluasi kewajaran solusi matematika dalam konteks masalah dunia nyata, karena subjek S2 tidak mampu memberikan kesimpulan atas jawaban yang telah dia berikan. Hasil ini didukung oleh hasil penelitian dari Fadillah \& Ni'mah (2019) yang menyatakan bahwa kemampuan menafsirkan merupakan salah satu aspek dalam literasi matematika cukup rendah, karena siswa kurang dalam menafsirkan .solusi matematis ke dalam bentuk matematika yang lebih sederhana. Jadi kesimpulannya, proses matematis yang dapat dicapai oleh subjek S2 yaitu dua proses dimana hanya proses matematis formulate dan employ yang subjek S2 belum mampu memenuhinya, sehingga dapat dikatakan bahwa kemampuan literasi matematis subjek S2 dalam kategori sedang karena dari tiga proses sudah dua proses yang mampu subjek S2 kerjakan.

Ditinjau dari proses literasi matematis formulate, subjek S3 sudah mampu mengidentifikasi aspek-aspek matematika dalam permasalahan yang terdapat pada situasi konteks nyata serta mengidentifikasi variabel yang penting, karena mampu menuliskan diketahui dan ditanyakan yang terdapat di dalam soal; mampu mengubah permasalahan menjadi bahasa matematika atau model matematika yang sesuai ke dalam bentuk variabel, gambar atau diagram yang sesuai karena mampu membuat permisalan mobil sedan dan mobil van sebagai variabel $x$ dan $y$. Ditinjau dari proses matematis employ, subjek S3 belum mampu menerapkan rancangan model matematika untuk menemukan solusi matematika, karena subjek S3 kurang tepat dalam menggunakan rancangan model matematika untuk menemukan solusi. Dimana siswa menuliskan bahwa:

$$
\left\{\begin{array}{c}
x+y=36 \ldots \\
400.000 x+600.000 y=17.000 .000
\end{array} \mid \frac{\times 2}{x 2}\right.
$$

Seharusnya penyelesaian yang benar yaitu dengan menggunakan cara mengeliminasi variabel $x$ dengan mengalikan persamaan satu dengan 400.000 dan persamaan dua dikalikan dengan satu, setelah itu dilanjutkan dengan mencari variabel $y$ dengan cara metode substitusi. Berdasarkan jawaban siswa tersebut, terlihat bahwa siswa kurang menguasai konsep pada materi spldv sehingga langkah-langkah penyelesaiannya yang digunakan masih kurang tepat serta keliru dalam melakukan perhitungan 
matematika. Hal ini didukung oleh hasil penelitian dari Wati \& Murtiyasa (2016) bahwa penyebab kesalahan siswa SMP dalam menyelesaikan soal matematika berkarakteristik PISA pada konten change and relationship adalah kemampuan penalaran dan kreativitas siswa yang rendah dalam memecahkan masalah konteks nyata dan memanipulasinya ke dalam bentuk aljabar. Sedangkan ditinjau dari proses literasi matematis interprete subjek S3 tidak mampu menafsirkan hasil matematika yang diperoleh dan mengevaluasi kewajaran solusi matematika dalam konteks masalah dunia nyata, karena subjek S3 tidak mampu memberikan kesimpulan atas jawaban yang telah dia berikan. Jadi kesimpulannya, proses matematis yang dapat dicapai oleh subjek S3 yaitu hanya proses matematis formulate saja yang subjek S3 mampu memenuhinya, sehingga dapat dikatakan bahwa kemampuan literasi matematis subjek S3 dalam kategori rendah karena dari tiga proses hanya satu proses yang mampu subjek S3 kerjakan.

\section{KESIMPULAN}

Berdasarkan uraian hasil dan pembahasan di atas, dapat disimpulkan bahwa kemampuan siswa berkemampuan tinggi menunjukkan performa literasi matematis yang baik, yakni siswa mampu memenuhi ketiga aspek proses matematis yaitu merumuskan, menerapkan dan menafsirkan hasil matematika ke dalam konteks dunia nyata. Siswa berkemampuan sedang hanya mampu memenuhi indikator pada aspek proses matematis yakni formulate dan employ. Siswa berkemampuan rendah memiliki kemampuan literasi matematis yang kurang baik, karena kurang tepat dalam menggunakan rancangan model matematika dalam menemukan solusi, tidak mampu menafsirkan hasil matematika yang diperoleh. Adapun kemampuan literasi matematis yang ditunjukkan siswa berkemampuan rendah yaitu mengidentifikasi aspek-aspek matematika dalam permasalahan yang terdapat pada situasi konteks nyata; mampu mengubah permasalahan menjadi model matematika yang sesuai ke dalam bentuk variabel.

Berdasarkan hal tersebut, guru perlu mengembangkan model pembelajaran untuk meningkatkan kemampuan literasi matematis siswa dalam menyelesaikan soal tipe PISA, serta guru perlu memberikan latihan soal-soal non rutin dengan hal tersebut siswa nantinya akan terbiasa dalam menyelesaikan soal bertipe PISA. Selain itu, bagi peneliti selanjutnya agar meneliti faktor-faktor yang mempengaruhi rendahnya kemampuan literasi matematis pada jenjang SMA/sederajat.

\section{UCAPAN TERIMA KASIH}

Penulis mengucapkan syukur kepada Allah SWT yang telah memberikan kelancaran dalam menyelesaikan penelitian artikel ini. Saya juga mengucapkan terimakasih kepada orang tua yang telah memberikan dukungan secara mental. Rasa terimakasih juga tidak lupa diucapkan kepada Dr. Abd. Qohar, M.T., dan Dr. Swasno Rahardjo, M.Si., selaku pembimbing tesis saya. Tidak lupa juga saya ucapkan terimakasih kepada guru dan siswa dari SMAN Mojoagung yang telah memberikan kesempatan kepada peneliti untuk melakukan penelitian di sekolah tersebut. 


\section{REFERENSI}

Ahyan, S., Zulkardi, \& Darmawijoyo. (2014). Developing mathematics problems based On PISA level of change and relationship contect. Journal on Mathematics Education, 5(1), 47-56. https://doi.org/10.22342/jme.5.1.1448.47-56

Baiduri. (2019). Strategi Literasi Dalam Pembelajaran Matematika Pada Era Industri 4.0. Journal of $\begin{array}{llll}\text { Mathematics Education, } & \text { Science and Technology, 4(1), }\end{array}$ http://dx.doi.org/10.30651/must.v4i1.2782

Dewantara, A.H., Zulkardi, \& Darmawijoyo. (2015). Assesing Seventh Graders' Mathematical Literacy in Solving PISA-Like Task. Journal on Mathematics Education,6(2), 39-49. https://doi.org/10.22342/jme.6.2.2163.117-128

Edo, S. I., Hartono, Y., \& Putri, R. I. I. (2013). Investigating secondary school students' difficulties in modeling problems PISA-model level 5 and 6. Journal on Mathematics Education, 4(1), 41-58. https://doi.org/10.22342/jme.4.1.561.41-58

Ehmke, T., Ham, A-K., Sälzer, C., Heine, J., \& Prenzel, M. (2020). Measuring mathematics competence in international and national large scale assessments: Linking PISA and the National Educational Panel Study in Germany. Studies in Educational Evaluation, 65, (100847). https://doi.org/10.1016/j.stueduc.2020.100847

Fadillah, A., \& Ni'mah. (2019). Analisis Literasi Matematika Siswa dalam Memecahkan Soal Matematika PISA Konten Change and Relationship. Jurnal Teori Dan Aplikasi Matematika, 3(2), 127-131. https://doi.org/10.31764/jtam.v3i2.1035

Genc, M., \& Erbas, A. K. (2019). Secondary Mathematics Teachers' Conceptions of Mathematical Literacy. International Journal of Education in Mathematics, Science and Technology (IJEMST), 7(3), 222-237.

Gomes, M., Hirata, G., \& Oliveira, J.B.A. (2020). Student composition in the PISA assessments: Evidence from Brazil. International Journal of Educational Development, 79. https://doi.org/10.1016/j.ijedudev.2020.102299

Gravemeijer, K., Stephan, M., Julie, C., Lin, F., Ohtani, M. (2017). What mathematics education may prepare students for the society of the future?. International Journal of Science and Mathematics Education, 15(1), 105-123. https://doi.org/10.1007/s10763-017-9814-6

Haara, F.O., Bolstad, O.H., \& Jenssen, E.S. 2017. Research on mathematical literacy in schools Aim, approach and attention. European Journal of Science and Mathematics Education, 5(3): 285-313. https://doi.org/10.30935/scimath/9512

Hesse, F., Care, E., Buder, J., Sassenberg, K., \& Griffin, P. (2015). A framework for teachable collaborative problem-solving skills. In Assessment and teaching of 21 st century skills (pp. 3756). Dordrecht: Springer. https://doi.org/10.1007/978-94-017-9395-7_2 
Hwang, J. \& Ham, Y. (2021). Relationship Between Mathematical Literacy and Opportunity to Learn With Different Types of Mathematical Tasks. Journal on Mathematics Education, 12(2), 199222. https://doi.org/10.22342/jme.12.2.13625.199-222

Jannah, R. D., Putri, R. I. I., \& Zulkardi. (2019). Soft Tennis and Volleyball Contexts in Asian Games For PISA-Like Mathematics Problems. Journal on Mathematics Education, 10(1), 157-170. https://doi.org/10.22342/jme.10.1.5248.157-170

Johar, R. (2012). Domain soal PISA untuk literasi matematika. Jurnal Peluang, 1(1), 30-41.

Julie, H., Sanjaya, F., \& Anggoro. A.Y. (2017). The Students' Ability in Mathematical Literacy for The Quantity, and The Change and Relationship Problems on The PISA Adaptation Test. Journal of Physics: Conf. Series 890 (2017) 012089.

Malasari, P. N., Herman, T., \& Jupri, A. (2017). The Construction of Matehmatical Literacy Problems for Geometri. Journal of Physics: Conf. Series $895 \quad$ (2017) 012071, 1-7. http://dx.doi.org/10.1088/1742-6596/895/1/012071

Moleong, L. J. (2016). Metodologi Penelitian Kualitatif Edisi Revisi. Bandung: PT.Remaja Rosdakarya.

Nizar, Harisman, Putri, R. I. I. dan Zulkardi (2018) "Developing pisa-like mathematics problem using the 2018 Asian Games football and table tennis context," Journal on Mathematics Education, 9(2), 183-194. doi: 10.22342/jme.9.2.5246.183-194.

Novita, R., Zulkardi, \& Hartono, Y. (2012). Exploring Primary Student's Problem Solving Ability by Doing Tasks Like PISA's Question. IndoMS. J.M.E, 3(2), 133-150. https://doi.org/10.22342/jme.3.2.571.133-150

Nugrahanto, S., \& Zuchdi, D. (2019). Indonesia PISA Result and Impact on The Reading Learning Program in Indonesia. In International Conference on Interdisciplinary Language, Literature and Education (ICILLE 2018). Atlantis Press. http://dx.doi.org/10.2991/icille-18.2019.77

Nusantara, D. S., Zulkardi, \& Putri, R. I. I. (2020a). Designing PISA-like mathematics problem in COVID-19 pandemic (PISAComat). Journal of Physics Conference Series, 1657(1), 012057. https://doi.org/10.1088/1742-6596/1657/1/012057

Nusantara, D. S., Zulkardi, \& Putri, R. I. I. (2020b). Designing PISA-like mathematics problem relating change and relationship using physical distancing context. Journal of Physics Conference Series, 1663(1), 012004. https://doi.org/10.1088/1742-6596/1663/1/012004

Nusantara, D. S., Zulkardi, \& Putri, R. I. I. (2021). Designing Pisa-Like Mathematics Task Using A Covid-19 Context (Pisacomat). Journal on Mathematics Education, 12 (2), 349-364. https://doi.org/10.22342/jme.12.2.13181.349-364

OECD. (2013). PISA 2012 Assessment and Analytical Framework: Mathematics, Reading, Science, Problem Solving and Financial Literacy. Paris: OECD Publishing.

OECD. (2019). PISA 2018: Insights and interpretations. Paris: OECD Publishing.

Permatasari, R., Putri, R.I.I., \& Zulkardi. (2018). PISA-like: Football context in Asian Games. Journal on Mathematics Education, 9(2), 271-280. https://doi.org/10.22342/jme.9.2.5251.271-280 
Putri, R. I. I. \& Zulkardi. (2018). Higher-order thinking skill problem on data representation in primary school: A case study. Journal of Physics Conference Series, 948(1), 012056. https://doi.org/10.1088/1742-6596/948/1/012056

Rizki, L.M., \& Priatna, N. (2019). Mathematical Literacy as The 21st Century Skill. Journal of Physics: Conference Series 1157 (2019) 042088. http://dx.doi.org/10.1088/1742-6596/1157/4/042088

Sari, R. H. N. (2015). Literasi Matematika: Apa , Mengapa dan Bagaimana? Seminar Nasional Matematika Dan Pendidikan Matematika, 713-720.

Seidel, T., \& Prenzel, M. (2008). Large scale assessment. In J. Hartig, E. Klieme, \& D. Leutner (Eds.). Assessment of competencies in educational contexts. State of the art and future prospects (pp. 279-304). Göttingen: Hogrefe \& Huber.

Van Laar, E., van Deursen, A.J.A.M., van Dijk, J.A.G.M., \& de Haan, J. (2020). Determinants of 21stCentury Skills and 21st-Century Digital Skills for Workers: A Systematic Literature Review. SAGE Open, 10 (1). https://doi.org/10.1177/2158244019900176

Wijaya, A., Van den Heuvel-Panhuizen, M., Doorman, M., \& Robitzsch, A. (2014). Difficulties in solving context-based PISA mathematics tasks: An analysis of students' error. The Mathematics Enthusiast, 11(3), 555-584.

Wijaya, A., Van den Heuvel-Panhuizen, M., Doorman, M. (2015). Opportunity to learn context-based tasks provided by mathematics textbooks. Educational Studies in Mathematics, 89, 41-65. https://doi.org/10.1007/s10649-015-9595-1

Yalcin, M., Aslan, S., \& Usta, E. 2012. Analysis of PISA 2009 Exam According to Some Variables. Mevlana International Journal of Education (MIJE), 2 (1): 64-71.

Y1lmazer, G., \& Masal, M. (2014). The Relationship between Secondary School Students' Arithmetic Performance and their Mathematical Literacy. Procedia Social and Behavioral Sciences, 152, (619-623). 